\title{
FIT2017 進捗報告
}

浜田 宏一

日立製作所

第 16 回情報科学技術フォーラム (FIT2017) が 2017 年 9 月 12 日（火） 14 日（木）の会期で東 京大学本郷キャンパス（東京都文京区本郷）に て開催される。

今回の FIT より査読付き論文を廃止し選奨論 文制度を導入する。論文の種類は選奨論文と一 般論文となり, 選奨論文の中から最も優秀な論 文 3 件以内が船井ベストペーパー賞に, 優秀な 論文 7 件程度が FIT 論文賞に選ばれる。また, 一般論文も含めた全ての発表のうち一定の年齢 制限，会員資格（詳細は [1] 参照）を満たすもの から FIT ヤングリサーチャー賞が選定される.

2013 年に創設された FIT 奨励賞を今年も実施 する。これは一般論文を対象に, 座長の裁量で 優秀な発表 1 件をセッション毎にその場で選定 する賞であり，昨年は 93 名が選定された．

情報科学分野に顕著な功績のある方に贈呈さ れる船井業績賞には, 厳正な審査により, 東京 大学名誉教授でマイクロソフトリサーチアジア 首席研究員の池内克史先生の受賞が決定してい る.「Computer Vision 分野に扔ける世界的研究 業績と人材育成」と題した記念講演が 9 月 13 日 (水)に表彰式に続いて行われる.

その他にも, 電子情報通信学会創立 100 周年 記念イベントや, 研究会や各種委員会等から提 案された多数のイベントが企画されている.

\section{9 月 12 日 (火)}

・デジタルゲリマンダーの脅威

・東大・情報理工研究 100 連発

・デー夕研磨によるビッグデータからの高精度 クラスタ発見とその応用
・画像・映像のプライバシー・イノベーション 検討 WG からの報告・提言

- 機械学習と量子物理学の交差点

・情報学的アプローチによる「情報科」大学入 学者選抜に扔ける評価手法の研究開発

・オープンデータ活用の最前線

- Joy, WorkPlace（仮） with 輪読会

9 月 13 日 (水)

・安全保障と社会を守るサイバーワールド

・デジタルとアナログの融合

- 電子情報通信学会創立 100 周年記念：人工知 能は人間の幸福度を測ることができるか? 主観的 QoL 計測に扮けるパターン認識・メ デイア理解技術の可能性を探る〜

・食の情報処理〜これまでの 10 年，これからの 10 年〜

・大学教育とラーニングアナリティクス基盤

9 月 14 日 (木)

・インターネットは心理学研究に FIT するか? ・不動産テック〜不動産× AI が拓く不動産の 未来

また，会期中は企業等による展示会の開催も 予定されている.

講演プログラムや会場情報などは，以下の FIT2017 の Web ページを御覧頂きたい. http:// www.ipsj.or.jp/event/fit/fit2017/index.html

なお，来年の FIT2018 は福岡工業大学での開 催が予定されている.

\section{参考文献}

[1] http://www.ipsj.or.jp/event/fit/fit2017/award. html 